\title{
Formation features of humoral immunity in newborn calves in case of including haylage with bio-preservative into the diet of cows
}

\author{
Anna Karamaeva ${ }^{1, *}$, Larisa Bakaeva $^{2}$, Natalia Soboleva ${ }^{2}$, and Sergey Karamaev ${ }^{1}$ \\ ${ }^{1}$ Samara state agricultural university, Uchebnaya St., 2, Kinel, Samara region, 446442, Russia \\ ${ }^{2}$ Orenburg state agricultural university, Chelyuskintsev St., 18, Orenburg, 460795, Russia
}

\begin{abstract}
The peculiarities of the formation of colostrum in the udder of cows and the immune status in the body of calves in the first hours and days after birth, when included in the diet of cows, haylage from eastern goat's rue prepared with the use of bio-preservatives "Silostan" (group II) and "GreenGrass $3 \times 3$ "(Group III). The study of colostrum of the first milk yield showed that feeding cows with silage with the bio-preservative "Silostan" contributed to an increase in the content of immunoglobulins by $4.0 \%(\mathrm{P}<0,001)$, with bio-preservative "GreenGras $3 \times 3$ " - by $5.3 \%$ $(\mathrm{P}<0,001)$. After drinking the first portion of colostrum, immunoglobulins appear in the blood serum of calves after 2 hours. After 6 hours, the content of immunoglobulins in the blood serum of calves of group II was $21.9 \%$ higher than in group I (haylage without preservative) $(\mathrm{P}<0.05)$, group III by $27.1 \%$ ( $\mathrm{P}<0.001)$. The proportion of calves with an immunoglobulin content 6 hours after the first feeding with colostrum not more than $6.0 \mathrm{mg}$ $/ \mathrm{ml}$, decreased in group II by $12.0 \%$, in group III - by $20.0 \%$.
\end{abstract}

\section{Introduction}

At the present stage of development in Russia of dairy cattle breeding, the problem of providing the population with natural milk and dairy products is very acute. Since the number of dairy cows has decreased by more than 8 times compared to 1990, the focus is on breeding highly productive animals. Since 2000, a large number of specialized dairy breeds have been imported into the country from Europe, America, Finland, Australia, Hungary, Czechoslovakia. At the same time, the main problem of breeding highly productive animals is to provide high quality feed with a high protein content. In the zone of the Middle Volga region, the main fodder crops of the legume family are alfalfa and eastern goat's rue. The main disadvantage of all legumes is the low sugar content, as a result of which the green mass is poorly silage and silage [1-4].

To solve this problem, scientists have developed dozens of different types of preservatives. In recent years, microbiological preparations "Silostan" and "GreenGras $3 \times 3$ " have been widely used for the production of haylage and silage. Biocon-sideboards contain a complex of hydrolytic enzymes, amino acids, vitamins and microelements as an active in-

\footnotetext{
* Corresponding author: annakaramaeva@rambler.ru
} 
gredient. They are based on the live microbial mass of bacterial strains: lactic acid streptococcus, lactic acid bacteria and propionic acid bacteria. Enzymes contribute to the stepwise degradation of cellulose, $\beta$-glucans and xylans of the plant cell. The carbohydrates formed as a result of hydrolysis are fermented by lactic acid and propionic acid bacteria. This makes it possible to increase the concentration of organic acids during the conservation of green mass poor in monosaccharides [5- 7].

Preliminary studies have shown that there were no side effects and complications in animals after feeding haylage prepared with bio-preservatives. At the same time, there are no data in the open press on the effect of eastern goat's rue haylage prepared with the use of Silostan and GreenGras $3 \times 3$ bio-preservatives on the quality of cow colostrum, the content of immunoglobulins in it, the peculiarities of the formation of the immune status in the first month of life, which determined the tasks of these studies.

\section{Materials and methods}

The research was carried out at the complex for the production of milk of LLC "Radna" of the Samara region on animals of the Ayrshire breed of the Finnish selection. The raw material for the production of haylage was the fodder crop of the legume family - the oriental goat's rue. Three silage trenches were laid: 1 trench - without preservative, 2 - with the biopreservative Silostan, 3 - with the bio-preservative GreenGras $3 \times 3$.

With year-round feeding of the same type, the rations for cows were based on the actual nutritional value of the feed, which is determined monthly, and the physiological state of the animals.

Blood for laboratory studies was taken from cows 90, 60, 30, 15, 5 and 1 day before the expected calving, immediately after calving and 1, 5, 10, 15, 30 days after calving; in newborn calves before colostrum intake, then every hour, in the first 6 hours, and then 12, 24, $36,48,72$ hours after birth. The content of immunoglobulins in the obtained blood serum samples was determined using a FEK-456M device under the conditions of a certified laboratory.

The first milking of cows was carried out 30 minutes after calving. Colostrum samples were placed in a 0.5 liter plastic bottle, frozen in a freezer and sent for research to the research laboratory of animal husbandry at the Samara State Agrarian University. In colostrum, the content of immunoglobulins was determined on a portable digital refractometer "PAL-Colostrum", mass fraction of fat (MJ), mass fraction of protein (BMP), lactose content on a high-speed infrared analyzer "Bentley 2000", quantitative content of protein fractions by densitometry of the obtained foregram on a microfotometer IFO-451, density and acidity of colostrum according to generally accepted methods.

According to the research results, the intensity of the transition of immunoglobulins from the blood of pregnant cows to colostrum was determined, and from colostrum of the first milk to the blood of newborn calves and the formation of colostral immunity in them. In the first 30 days of calves' life, all signs of health disorders were recorded, and the results were used to determine the incidence rate in different age periods.

\section{Research results}

Studies have shown that feeding cows with haylage prepared without a preservative and with a preservative, due to the differences in its quality, has a significant effect on the immune status of cows before calving (Table 1).

Table 1. The content of immunoglobulins in the blood serum of cows before and after calving, $\mathrm{mg} / \mathrm{ml}$ 


\begin{tabular}{|c|c|c|c|}
\hline \multirow{2}{*}{ Indicator } & \multicolumn{3}{|c|}{ Silage preparation method } \\
\cline { 2 - 4 } & \begin{tabular}{c} 
with preservative \\
no preservative \\
\cline { 3 - 4 }
\end{tabular} & $\begin{array}{c}\text { I group } \\
\text { II group }\end{array}$ & $\begin{array}{c}\text { "GreenGrass } 3 \times \\
\text { III group }\end{array}$ \\
\hline $\begin{array}{c}\text { Days before calving: } \\
90\end{array}$ & $21.56 \pm 0.48$ & $23.38 \pm 0.52$ & $23.64 \pm 0.43$ \\
\hline 60 & $21.89 \pm 0.53$ & $23.81 \pm 0.64$ & $24.09 \pm 0.45$ \\
\hline 30 & $23.76 \pm 0.59$ & $26.13 \pm 0.62$ & $26.60 \pm 0.50$ \\
\hline 15 & $24.11 \pm 0.64$ & $26.76 \pm 0.57$ & $27.38 \pm 0.52$ \\
\hline 5 & $21.93 \pm 0.67$ & $24.23 \pm 0.64$ & $24.66 \pm 0.49$ \\
\hline 1 & $19.99 \pm 0.71$ & $21.98 \pm 0.69$ & $22.35 \pm 0.51$ \\
\hline $\begin{array}{c}\text { Immediately after } \\
\text { calving }\end{array}$ & $19.93 \pm 0.65$ & $21.92 \pm 0.68$ & $22.31 \pm 0.48$ \\
\hline Days after calving: & $19.63 \pm 0.59$ & $21.63 \pm 0.65$ & $22.05 \pm 0.47$ \\
\hline 1 & $19.25 \pm 0.54$ & $21.32 \pm 0.67$ & $21.78 \pm 0.47$ \\
\hline 5 & $19.49 \pm 0.57$ & $21.61 \pm 0.68$ & $22.12 \pm 0.49$ \\
\hline 10 & $19.86 \pm 0.62$ & $22.09 \pm 0.66$ & $22.68 \pm 0.52$ \\
\hline 15 & $20.37 \pm 0.64$ & $22.76 \pm 0.69$ & $23.43 \pm 0.54$ \\
\hline 30 & \multicolumn{3}{|c}{} \\
\hline
\end{tabular}

It was found that in cows of group II, fed with silage with bioconservative "Silostan", the content of immunoglobulins in blood serum 90 days before calving was higher than in group I by $1.82 \mathrm{mg} / \mathrm{ml}(8.4 \%$; P $<0.05)$, and in group III, who received a session with the bio-preservative "GreenGras $3 \times 3$ ", by $2.08 \mathrm{mg} / \mathrm{ml}(9.7 \%$; P <0.01). It was found that during the dry period there is an increase in the content of immunoglobulins in the blood serum. The maximum content of immunoglobulins was noted 15 days before calving. The difference between groups II and III, compared with I, was $2.65 \mathrm{mg} / \mathrm{ml}(11.0 \% ; \mathrm{P}<0.01)$ and $3.27 \mathrm{mg} / \mathrm{ml}(13.6 \%$; $\mathrm{P}<0.001)$, respectively.

15 days before calving, a decrease in the content of immunoglobulins is observed in the blood serum of cows, which is presumably associated with the process of colostronenesis, which occurs in the cells of the secretory epithelium of the alveoli in the udder of cows. 5 days before calving, their content decreased in group I cows by $2.18 \mathrm{mg} / \mathrm{ml}(9.0 \%$; P $<0.05)$, in group II - by $2.53 \mathrm{mg} / \mathrm{ml}(9.5 \%$; P $<0.01)$, group III - by $2.72 \mathrm{mg} / \mathrm{ml}(9.9 \%$; P $<0.001)$, and 1 day before calving, respectively, by another $1.94 \mathrm{mg} / \mathrm{ml}(8.8 \%$; $\mathrm{P}<0.05)$, $2.25 \mathrm{mg} / \mathrm{ml}(9.3 \% ; \mathrm{P}<0.05)$ and $2.31 \mathrm{mg} / \mathrm{ml}(9.4 \% ; \mathrm{P}<0.01)$. The day before calving, the dynamics of immunoglobulins in the blood serum of cows practically stops. At the same time, a decrease in the content of immunoglobulins in the blood serum of cows up to the 5 th day after calving can be noted, respectively by groups by $0.68 \mathrm{mg} / \mathrm{ml}(3.4 \%) ; 0.60$ $\mathrm{mg} / \mathrm{ml}(2.7 \%) ; 0.53 \mathrm{mg} / \mathrm{ml}(2.4 \%)$. From the 5 th day after calving, the process of restoration of the immune status begins in the body of cows due to a slight but dynamic increase in immunoglobulins in the blood serum.

Chemical analysis of the secretion of the mammary gland (colostrum), obtained from cows 30-45 minutes after calving, showed that it differs significantly from ordinary milk in terms of the content of the main components (Table 2).

Table 2. Chemical composition of colostrum of the first milk yield, $\%$

\begin{tabular}{|c|c|c|c|}
\hline \multirow{2}{*}{ Indicator } & \multicolumn{3}{|c|}{ Silage preparation method } \\
\cline { 2 - 4 } & no preservative & \multicolumn{3}{|c|}{ with preservative } \\
\cline { 3 - 4 } & I group & "Silostan" & "Greengrass 3 $\times$ \\
\hline
\end{tabular}




\begin{tabular}{|l|c|c|c|}
\hline & & II group & $\begin{array}{c}\text { 3" } \\
\text { III group }\end{array}$ \\
\hline dry matter & $33.86 \pm 0.21$ & $35.64 \pm 0.27$ & $36.28 \pm 0.19$ \\
\hline $\begin{array}{l}\text { washing disinfectant } \\
\text { liquid }\end{array}$ & $7.85 \pm 0.06$ & $8.36 \pm 0.05$ & $8.42 \pm 0.08$ \\
\hline $\begin{array}{l}\text { mass fraction of protein, } \\
\text { total: }\end{array}$ & $22.64 \pm 0.13$ & $23.48 \pm 0.15$ & $23.86 \pm 0.16$ \\
\hline including casein & $6.82 \pm 0.04$ & $6.27 \pm 0.07$ & $6.35 \pm 0.05$ \\
\hline \multicolumn{1}{|c|}{ albumen } & $6.73 \pm 0.03$ & $7.31 \pm 0.05$ & $7.36 \pm 0.05$ \\
\hline \multicolumn{1}{|c|}{ globulin } & $9.09 \pm 0.10$ & $9.90 \pm 0.15$ & $10.15 \pm 0.12$ \\
\hline lactose & $2.13 \pm 0.02$ & $2.31 \pm 0.03$ & $2.43 \pm 0.02$ \\
\hline minerals & $1.24 \pm 0.03$ & $1.49 \pm 0.03$ & $1.57 \pm 0.02$ \\
\hline
\end{tabular}

It was found that the introduction of haylage with bio-preservatives into the diet of cows during the dry period had a positive effect on the chemical composition of colostrum. When feeding haylage with the bio-preservative "Silostan", the mass fraction of fat (MJ) in colostrum increased by $0.51 \%(\mathrm{P}<0.001)$, with the bio-preservative "GreenGras $3 \times 3$ " - by $0.57 \%(\mathrm{P}<0.001)$; mass fraction of proteins $(\mathrm{MBP})$, respectively by $0.84 \%(\mathrm{P}<0.001)$ and $1.22 \%$ ( $<<0.001)$, lactose content - by $0.18 \%(\mathrm{P}<0.001) ; 0.30 \%(\mathrm{P}<0.001)$, the content of minerals - by $0.25 \%(\mathrm{P}<0.001), 0.33 \%(\mathrm{P}<0.001)$.

Among the protein fractions, globulins are the most numerous and significant for the life support of newborns. In colostrum of the first days after calving, the bulk of globulins are immunoglobulins, which contribute to the formation of colostral immunity in the body of calves (Table 3 ).

Table 3. Change in the content of immunoglobulins in the secretion of the mammary gland during the colostrum period

\begin{tabular}{|c|c|c|c|}
\hline \multirow{2}{*}{ Indicator } & \multicolumn{3}{|c|}{ Silage preparation method } \\
\cline { 2 - 4 } & no preservative & \multicolumn{2}{c|}{ с консервантом } \\
\cline { 2 - 4 } & I group & $\begin{array}{c}\text { "Silostan" } \\
\text { II group }\end{array}$ & $\begin{array}{c}\text { "Greengrass } 3 \times \\
\text { 3" } \\
\text { III group }\end{array}$ \\
\hline \multicolumn{3}{|c|}{ Первые сутки после отела } \\
\hline Total immunoglobulins & $80,19 \pm 0,62$ & $83,37 \pm 0,73$ & $84,45 \pm 0,67$ \\
\hline incl. class G & $69,14 \pm 0,51$ & $71,52 \pm 0,59$ & $72,25 \pm 0,64$ \\
\hline class A & $6,98 \pm 0,34$ & $7,59 \pm 0,38$ & $7,63 \pm 0,31$ \\
\hline class M & $4,07 \pm 0,23$ & $4,26 \pm 0,27$ & $4,57 \pm 0,29$ \\
\hline & The second day after calving \\
\hline Total immunoglobulins & $40,26 \pm 0,36$ & $43,94 \pm 0,41$ & $45,83 \pm 0,34$ \\
\hline incl. class G & $34,65 \pm 0,27$ & $37,24 \pm 0,29$ & $38,49 \pm 0,25$ \\
\hline class A & $4,62 \pm 0,16$ & $5,31 \pm 0,18$ & $5,53 \pm 0,16$ \\
\hline class M & $0,99 \pm 0,11$ & $1,39 \pm 0,09$ & $1,81 \pm 0,12$ \\
\hline \multicolumn{4}{|c|}{ Third day after calving } \\
\hline Total immunoglobulins & $3,72 \pm 0,13$ & $4,16 \pm 0,15$ & $4,54 \pm 0,14$ \\
\hline incl. class G & $0,11 \pm 0,001$ & $0,13 \pm 0,001$ & $0,14 \pm 0,001$ \\
\hline class A & $2,87 \pm 0,10$ & $3,10 \pm 0,14$ & $3,32 \pm 0,13$ \\
\hline class M & $0,74 \pm 0,05$ & $0,93 \pm 0,07$ & $1,08 \pm 0,06$ \\
\hline
\end{tabular}


The study of colostrum of the first milk yield showed that feeding cows with silage with the bio-preservative "Silostan" contributed to an increase in the content of immunoglobulins by $3.18 \mathrm{~g} / 1(4.0 \%$; P $<0.001)$, with the bio-preservative "GreenGras $3 \times 3$ " - by $4.26 \mathrm{~g} / 1$ $(5.3 \% ; \mathrm{P}<0.001)$. At the same time, the proportion of class $\mathrm{G}$ immunoglobulins increased, respectively, by $2.38 \mathrm{~g} / 1(3.4 \%$; $\mathrm{P}<0.01) ; 3.11 \mathrm{~g} / 1(4.5 \%$; $\mathrm{P}<0.001)$, class A immunoglobulins - by $0.61 \mathrm{~g} / \mathrm{l}(8.7 \%) ; 0.65 \mathrm{~g} / \mathrm{l}(9.3 \%)$, class M - by $0.19 \mathrm{~g} / \mathrm{l}(4.7 \%) ; 0.50 \mathrm{~g} / \mathrm{l}(12.3 \%)$.

After calving, with each subsequent milking, the content of immunoglobulins in colostrum decreases. On the second day after calving, the total content of immunoglobulins in the colostrum of cows in group I decreased by $39.93 \mathrm{~g} / 1(49.8 \%$; $\mathrm{P}<0.001)$, in group II - by $39.43 \mathrm{~g} / \mathrm{l}(47.3 \%$; $\mathrm{P}<0.001)$, group III - by $38.62 \mathrm{~g} / \mathrm{l}(45.7 \%$; $\mathrm{P}<0.001)$, on the third day, respectively, by $76.47 \mathrm{~g} / 1(95.4 \%$; $\mathrm{P}<0.001) ; 79.21 \mathrm{~g} / 1(95.0 \% ; \mathrm{P}<0.001) ; 79.91 \mathrm{~g} / 1$ (94.6\%; P <0.001). By the end of the third day after calving, "traces" of immunoglobulins remain in the milk, which is a very important moment in the formation of the immune status in newborn calves.

In the body of newborn calves, which are born completely sterile, there are practically no immunoglobulins at all. After drinking the first portion of colostrum, the appearance of immunoglobulins in the blood serum of calves was noted after 2 hours (Table 4).

Table 4. Dynamics of immunoglobulins in the blood serum of newborn calves after drinking colostrum, $\mathrm{mg} / \mathrm{ml}$

\begin{tabular}{|c|c|c|c|}
\hline \multirow{3}{*}{$\begin{array}{l}\text { Time after drinking the } \\
\text { first portion of colostrum, } \\
h\end{array}$} & \multicolumn{3}{|c|}{ Silage preparation method } \\
\hline & \multirow[b]{2}{*}{$\begin{array}{l}\text { no preservative } \\
\text { I group }\end{array}$} & \multicolumn{2}{|c|}{ with preservative } \\
\hline & & $\begin{array}{l}\text { "Silostan" } \\
\text { II group }\end{array}$ & $\begin{array}{c}\text { "GreenGrass } 3 \times \\
3 " \\
\text { III group }\end{array}$ \\
\hline Before colostrum intake & $0,21 \pm 0,02$ & $0,19 \pm 0,03$ & $0,22 \pm 0,02$ \\
\hline 1 & $0,34 \pm 0,17$ & $0,39 \pm 0,14$ & $0,41 \pm 0,10$ \\
\hline 2 & $2,32 \pm 0,29$ & $2,65 \pm 0,26$ & $2,79 \pm 0,21$ \\
\hline 3 & $5,19 \pm 0,34$ & $5,83 \pm 0,39$ & $6,13 \pm 0,33$ \\
\hline 4 & $6,08 \pm 0,39$ & $6,94 \pm 0,37$ & $7,42 \pm 0,34$ \\
\hline 5 & $7,16 \pm 0,45$ & $8,11 \pm 0,48$ & $8,73 \pm 0,42$ \\
\hline 6 & $8,91 \pm 0,54$ & $10,86 \pm 0,53$ & $11,32 \pm 0,48$ \\
\hline 12 & $14,15 \pm 0,63$ & $15,49 \pm 0,66$ & $16,23 \pm 0,59$ \\
\hline 24 & $21,14 \pm 0,72$ & $22,87 \pm 0,70$ & $23,92 \pm 0,65$ \\
\hline 36 & $21,45 \pm 0,76$ & $23,21 \pm 0,68$ & $24,31 \pm 0,63$ \\
\hline 48 & $21,58 \pm 0,70$ & $23,36 \pm 0,65$ & $24,49 \pm 0,69$ \\
\hline 72 & $21,48 \pm 0,61$ & $23,25 \pm 0,60$ & $24,35 \pm 0,64$ \\
\hline
\end{tabular}

Depending on the quality of colostrum, the content of the main constituents in it, which was significantly influenced by the nutritional value of feed for cows and, to a certain extent, the method of their preparation, the intensity of the passage of immunoglobulins through the walls of the small intestine into the blood system of calves was different. 6 hours after drinking the first portion of colostrum, the content of immunoglobulins in the blood serum of group II calves whose mothers received silage with the bioconservative Silostan was higher than in group I by $1.95 \mathrm{mg} / \mathrm{ml}(21.9 \%$; P $<0,05)$; Group III, who received silage with the bio-preservative "GreenGras $3 \times 3$ " - by $2.41 \mathrm{mg} / \mathrm{ml}(27.1 \%$; P $<0.001)$. After 12 hours, the difference in the content of immunoglobulins between the groups of calves was $1.34 \mathrm{mg} / \mathrm{ml}(9.5 \%)$ and $2.08 \mathrm{mg} / \mathrm{ml}(14.7 \%$; $\mathrm{P}<0.05)$, respectively, after 24 hours $-1.73 \mathrm{mg} / \mathrm{ml}(8.2 \%) ; 2.78 \mathrm{mg} / \mathrm{ml}(13.2 \%$; $\mathrm{P}<0.01)$, after 36 hours -1.76 $\mathrm{mg} / \mathrm{ml}(8.2 \%) ; 2.86 \mathrm{mg} / \mathrm{ml}(13.3 \% ; \mathrm{P}<0.01)$. The highest content of immunoglobulins in 
the blood serum of calves was noted 48 hours after drinking the first portion of colostrum, respectively by groups - 21.58; $23.36 ; 24.49 \mathrm{mg} / \mathrm{ml}$.

The formation of colostral immunity in the body of newborns is determined by the amount of immunoglobulins in colostrum and the intensity of their transition into the blood serum of calves, especially in the first 6 hours after drinking the first portion of colostrum (Table 5).

Table 5. The intensity of the transition of immunoglobulins from colostrum to the blood serum of calves in the first 6 hours after drinking

\begin{tabular}{|c|c|c|c|c|c|c|}
\hline \multirow{4}{*}{$\begin{array}{l}\text { The content of im- } \\
\text { munoglobulins in } \\
\text { blood serum, } \\
\mathrm{mg} / \mathrm{ml}\end{array}$} & \multicolumn{6}{|c|}{ Silage preparation method } \\
\hline & \multirow{2}{*}{\multicolumn{2}{|c|}{$\begin{array}{l}\text { no preservative } \\
\text { I group }\end{array}$}} & \multicolumn{4}{|c|}{ с консервантом } \\
\hline & & & \multicolumn{2}{|c|}{$\begin{array}{l}\text { "Silostan" } \\
\text { II group }\end{array}$} & \multicolumn{2}{|c|}{$\begin{array}{c}\text { "Greengrass } 3 \times 3 " \\
\text { III group }\end{array}$} \\
\hline & units & $\%$ & units & $\%$ & units & $\%$ \\
\hline To 4,0 & 3 & 12,0 & 2 & 8,0 & 1 & 4,0 \\
\hline $4,1-6,0$ & 4 & 16,0 & 2 & 8,0 & 1 & 4,0 \\
\hline $6,1-8,0$ & 2 & 8,0 & 1 & 4,0 & 3 & 12,0 \\
\hline $8,1-10,0$ & 4 & 16,0 & 3 & 12,0 & 1 & 4,0 \\
\hline $10,1-12,0$ & 7 & 28,0 & 8 & 32,0 & 10 & 40,0 \\
\hline Over 12,0 & 5 & 20,0 & 9 & 36,0 & 9 & 36,0 \\
\hline
\end{tabular}

As practice shows, calves, in which, 6 hours after drinking the first portion of colostrum, the content of immunoglobulins in the blood serum does not exceed $6.0 \mathrm{mg} / \mathrm{ml}$, almost $100 \%$ are susceptible to various diseases, with an Ig content in the range of $6.1-10,0$ $\mathrm{mg} / \mathrm{ml}$ are at risk and only calves with an Ig content of $10.1 \mathrm{mg} / \mathrm{ml}$ or more have a relatively reliable protection due to the properties of immunoglobulins.

It was found that when haylage with bio-preservatives was introduced into the diet of cows, the number of animals with good digestibility of immunoglobulins increased among newborns. The proportion of calves with a serum immunoglobulin content of up to 6.0 $\mathrm{mg} / \mathrm{ml}$ decreased in group II by $12.0 \%$, in group III - by $20.0 \%$, with an immunoglobulin content in the range of $6.1-10.0 \mathrm{mg} / \mathrm{ml}$ decreased in both groups by $8.0 \%$. At the same time, the proportion of calves with an immunoglobulin content of $10.1 \mathrm{mg} / \mathrm{ml}$ and more increased in group II by $20.0 \%$, in group III - by $28.0 \%$.

An increase in the intensity of the transition of immunoglobulins from milk to serum in the body of calves had a positive effect on the formation of colostral immunity, as a result of which their incidence decreased in the first month after birth (Table 6).

Table 6. Morbidity of calves in the first month after birth

\begin{tabular}{|c|c|c|c|c|c|c|}
\hline \multirow{4}{*}{ Calf age, days } & \multicolumn{6}{|c|}{ Silage preparation method } \\
\hline & \multirow{2}{*}{\multicolumn{2}{|c|}{$\begin{array}{l}\text { no preservative } \\
\text { I group }\end{array}$}} & \multicolumn{4}{|c|}{ с консервантом } \\
\hline & & & \multicolumn{2}{|c|}{$\begin{array}{l}\text { "Silostan" } \\
\text { II group } \\
\end{array}$} & \multicolumn{2}{|c|}{$\begin{array}{c}\text { "Greengrass } 3 \times 3 " \\
\text { III group }\end{array}$} \\
\hline & units & $\%$ & units & $\%$ & units & $\%$ \\
\hline $1-5$ & 6 & 24,0 & 3 & 12,0 & 3 & 12,0 \\
\hline $6-10$ & 2 & 8,0 & 2 & 8,0 & 1 & 4,0 \\
\hline $11-15$ & 1 & 4,0 & - & - & 1 & 4,0 \\
\hline $16-20$ & - & - & 1 & 4,0 & - & - \\
\hline $21-30$ & - & - & - & - & - & - \\
\hline $\begin{array}{l}\text { Total diseases per } \\
\text { month }\end{array}$ & 9 & 36,0 & 6 & 24,0 & 5 & 20,0 \\
\hline Fatal cases & 6 & 24,0 & 3 & 12,0 & 2 & 8,0 \\
\hline
\end{tabular}


Observations of the health of newborns showed that in the first 5 days of life in group I $24.0 \%$ of calves fell ill, or $66.7 \%$ of all cases in the first month of life, in group II, respectively 12.0 and $50.0 \%$, in Group III -12.0 and $60.0 \%$. In total, during the first month of life in group I, $36.0 \%$ of calves fell ill, in group II $-24.0 \%$, in group III $-20.0 \%$. The disease was fatal in group I in $24.0 \%$ of calves, in group II $-12.0 \%$, in group III $-8.0 \%$.

\section{Discussion}

Colostrum plays a very important role in the life support of newborn calves, especially in the first 15 days after birth, until permanent immunity is developed in their body. Since the mother's placenta, being a certain biological filter, does not allow anything superfluous to the calf, including antibodies that provide a protective function, it is born completely "sterile". Therefore, antibodies (immunoglobulins) are transported from the mother's body to the calf's body through colostrum.

The formation of colostrum in the cells of the secretory epithelium of the alveoli begins in the second half of the dry period. J. D. Quigley [8], P. P. Pithua [9], G. N. Calla-han [10], A. Fox, S. Patel [11] established that the process of colostrogenesis begins several weeks before calving. The process is regulated by the hormone progesterone. During dry periods, progesterone molecules bind to specific receptors in the basement membrane of secretory epithelial cells and prevent milk secretion. About two weeks before calving, the level of the hormone estrogen begins to rise in the blood of the cows and the concentration of progesterone decreases. This is due to the fact that during this period of pregnancy, specific receptors are formed on the basement membranes of the cells of the secretory epithelium of the alveoli, which facilitate the transfer of substances, including immunoglobulins, from the cow's blood into the cavity of the secretory cells, where they are concentrated until calving.

The research results showed that the use of modern 3rd generation bio-preservatives "Silostan" and 4th generation "GreenGras $3 \times 3$ " for silage of the green mass of alfalfa and eastern goat's rue had a positive effect on the quality of the finished feed, its nutritional value and preservation. Thanks to this, in the experimental groups, an increase in milk yield in cows and an improvement in the chemical composition of milk was achieved. It was found that before the start in the blood serum of cows of groups II and III, the content of immunoglobulins was higher by $8.4-9.7 \%$.

15 days before calving, a decrease in the concentration of immunoglobulins is observed in the blood serum of cows, which characterizes the beginning of the process of colostrogenesis and an increase in the intensity of the transition of immunoglobulins from the blood serum to the alveoli of the mammary gland. According to P. P. Pithua [9], a few days before calving, the hormone prolactin is activated, which is responsible for the differentiation of alveolar cells. This serves as a kind of signal for the onset of lactogenesis and the termination of colostrogenesis. By this time, the level of progesterone in the blood of cows decreases sharply, which removes its inhibitory function after the process of lactogenesis. In this regard, the negative dynamics of the content of immunoglobulins in the blood serum of cows one day before calving stops almost completely.

Due to the morphological and physiological characteristics of the digestive system of newborn calves, colostrum is the only food for them and a source of nutrients, biologically active substances and energy. The study of the chemical composition of colostrum of the first milk yield showed that compared to natural milk, the content of fat in it is 2.2-2.4 times higher, proteins - 6.9-7.2 times, globulins - 90 -100 times, minerals - 1.6-2.0 times, lactose, at the same time, 2.3-2.0 times less. This is very important, since the body of newborn calves does not release the enzyme lactase, which breaks down lactose.

It should be noted that feeding the cows with haylage with bio-preservatives had a positive effect on improving the chemical composition of colostrum. It was found that when 
silage with the bio-preservative "GreenGras $3 \times 3$ " was introduced into the diet, compared with group II, where haylage with the bio-preservative "Silostan" was used, the MJ in colostrum of the first milk yield was higher by $0.06 \%$, the MDB - by $0.38 \%$, including casein - by $0.08 \%$, albumin - by $0.05 \%$, globulins - by $0.25 \%$, lactose content - by $0.12 \%$, mineral substances - by $0.08 \%$.

The protective function of colostrum is due to the content of globulins in it. The share of globulins in the total mass of proteins in the colostrum of cows fed with haylage without preservative is $40.2 \%$, with the preservative "Silostan" - 42.2\%, "GreenGras $3 \times 3$ " $-42.5 \%$. In this case, the globulin fraction of colostrum proteins is represented mainly by immunoglobulins.

As noted above, colostrum immunoglobulins, depending on their properties and functions, are divided into three classes: IgG, IgA, IgM. At the same time, J. D. Quigley [8] found that IgG and IgM enter colostrum directly from the blood serum of cows, and IgA is synthesized in the secretory epithelium of the udder alveoli. Since before calving, due to hormonal changes in the body of cows, the process of transition of immunoglobulins from blood to colostrum stops, after calving, with each subsequent milking, their content in colostrum decreases.

It has been established that the positive effect of feeding haylage with bio-preservatives is, firstly, that the content of immunoglobulins in cow colostrum is higher by $4.0-5.3 \%$; secondly, the decrease in the content of immunoglobulins occurs more slowly: on the second day after calving in group II by $2.5 \%$, in group III - by $4.1 \%$, on the third day, by 0.3 and $0.7 \%$, accordingly.

Since the decrease in the content of immunoglobulins in colostrum occurs relatively quickly, during the formation of the immune status of calves, it is very important to drink the first portion. In this case, along with the drinking time, the volume of drinking the first portion of colostrum, the intensity of the transition of immunoglobulins from colostrum to the blood serum of calves is of decisive importance. In order to ensure reliable protection of the newborn's body, it is necessary that 6 hours after the first portion of colostrum is fed, the content of immunoglobulins in the blood serum of calves should be at least $10 \mathrm{mg} / \mathrm{ml}$ [12-16].

Studies have shown that in group I calves, whose mothers received hay without preservative, the content of immunoglobulins in the blood serum, 6 hours after the first portion of colostrum, did not reach the physiological norm. Due to the fact that in the blood serum of calves of groups II and III, the content of immunoglobulins was higher than in group I, by 21.9 and $27.1 \%$, it can be assumed that this is the influence of biocon-servants, which were used for preparation of silage and the quality of silage obtained by this technology.

According to scientists from Europe, about $23 \%$ of newborn calves of the Holstein breed practically do not assimilate colostrum immunoglobulins at all and, as a rule, die from various infections [9, 17-19].

It was found that feeding Ayrshire cows with bio-preservatives helps to reduce the number of calves that do not accept immunoglobulins from colostrum. In group I, the proportion of calves in which, 6 hours after drinking the first portion of colostrum, the content of immunoglobulins in the blood serum did not exceed $6.0 \mathrm{mg} / \mathrm{ml}$ was $28.0 \%$, in group II $16.0 \%$, in Group III - 8.0\%.

This fact is very important, as it affects the incidence and safety of calves. Almost all calves, in which the content of immunoglobulins in the blood serum was no more than 8.0 $\mathrm{mg} / \mathrm{ml}$ (ie, the calves "critical group" and part of the "risk group"), during the first 15 days of life, had gastrointestinal diseases. - intestinal diseases. At the same time, in $24.0 \%$ of calves from group I, $12.0 \%$ from group II and $8.0 \%$ from group III, the disease was fatal in the first 5 days of life. 


\section{Conclusion}

Thus, the use of the oriental bio-preservatives Silostan and GreenGras $3 \times 3$ for silage of green mass of alfalfa and goat grass allows not only to prepare high-quality feed and preserve its nutritional value for a long time, but also has a positive effect on the quality of cow colostrum ... The content of immunoglobulins in colostrum increases by $4.0-5.3 \%$ (P $<0.001)$, the intensity of their transition to the blood serum of calves increases, which contributes to the improvement of the immune status by $21.9 \%(\mathrm{P}<0.05)$ and $27,1 \%(\mathrm{P}$ $<0.001$ ) and a decrease in the incidence of young animals by $12.0-16.0 \%$.

\section{References}

1. S.D. Batanov, O.S. Starostina, I.A. Baranova, IOP Conference Series: Earth and Environmental Science 548(3), 032023 (2020) doi: 10.1088/1755-1315/548/3/032023

2. I.V. Mironova, V.I. Kosilov, Nigmatyanov et al., Research journal of Pharmaceutical, Biological, and Chemical Sciences 6, 18-25 (2018)

3. S.N. Shlukov, I.F. Gorlov, A.V. Guzenko et al. Research journal of Pharmaceutical, Biological, and Chemical Sciences 4, 1714-1717 (2016)

4. Kh.Kh. Tagirov, N.M. Gubaidullin, I.R. Fakhretdinov et al, Journal of Engineering and Applied Sciences 58, 6597-6603 (2018)

5. L.J. Kung, Department of Animal and Food Sciences. University of Delaware Newark, 19717-1303 (2010)

6. K.M. Mendonsa, California Polytechnic State University, 32 (2011)

7. R.R. Sakai, D.M. Coons, M. Chigerve, Liverstock Science, 296-299 (2012)

8. J.D. Quigley, A. Lago, C. Chapman, P. Erickson, J. Polo, J. Dairy Sci, 1148-1155 (2013)

9. P.P. Pithua, S.S. Aly, Intern. J. Appl. Res. Vet. Med 1, 77-83 (2013)

10. G.N. Callahan, R.M. Yates, University Press Colorado Boulder, 337 (2014)

11. S. Patel, J. Gibbons, D.C. Wathes, Cattle Practice 22(1), 95-104 (2014)

12. M. Conneely, D.P. Berry, R. Sayers, J.P. Murphy, et al., J. Dairy Sci, 97, 6991-7000 (2014)

13. K. Furman-Fratczak, A. Rzasa, T. J. Stefaniak, Dairy Sci 94, 5536-5543 (2011)

14. T. Mejer, Aarhus University, 51 (2015)

15. S.V. Karamaev, L. N.Bakaeva, Kh. Z. Valitov et al. Research Journal of Pharmaceutical, Biological and Chemical Sciences 5, 1429-1439 (2018)

16. S.V. Karamaev, A.S. Karamaeva, Kh. Z. Valitov et al., BIO Web of Conferences, 00008 (2020)

17. C.R. Baumrucker, A.M. Burkett, A.L. Magliaro-Macrina, C.D. Dechow, J. Dairy Sci 93(7), 3031-3038 (2010)

18. J. Krol, Z. Litwinczuk, A. Brodziak, J. Barolowska, Polish J. Vet. Sci. 2, 357-361 (2010)

19. I.R. Tizard, Veterinary Immunology. Ninth edition, Elsevier, 225-239 (2013) 